\title{
ИНВЕНТАРИЗАЦИЯ ЗЕМЕЛЬНО-ИМУЩЕСТВЕННОГО КОМПЛЕКСА МУНИЦИПАЛЬНОГО ОБРАЗОВАНИЯ: ОСНОВНЫЕ ХАРАКТЕРИСТИКИ
}

\author{
Дарина Сергеевна Шулбаева \\ Сибирский государственный университет геосистем и технологий, 630108, Россия, г. Новоси- \\ бирск, ул. Плахотного, 10, обучающийся, тел. (902)468-44-87, e-mail: dshulb@mail.ru
}

Проведен анализ инвентаризации земельно-имущественного комплекса муниципального образования в контексте основных характеристик. Методы исследования: индукция, аналитический метод, наблюдение.

Ключевые слова: инвентаризация, муниципальные образования, законодательство, региональные власти

\section{INVENTORY OF LAND-PROPERTY COMPLEX OF MUNICIPAL EDUCATION: MAIN CHARACTERISTICS}

\section{Darina S. Shulbaeva}

Siberian State University of Geosystems and Technologies, 10, Plakhotnogo St., Novosibirsk, 630108, Russia, Student, phone: (902)468-44-87, e-mail: dshulb@mail.ru

The analysis of the inventory of the land and property complex of the municipality in the context of the main characteristics. Research methods: induction, analytical method, observation.

Keywords: inventory, municipalities, legislation, regional authorities

В настоящее время инвентаризация земельно-имущественного комплекса рассматривается в качестве инструмента фактического и документального контроля в отношении земельных участков и объектов, размещенных на них. Инвентаризация направлена на актуализацию данных кадастрового учета, является средством выявления нарушений в сфере землепользования. Проведение работ организуется в соответствии с методическими рекомендациями, которые утверждаются региональными властями. Так, на территории Новосибирской области разработаны методические рекомендации, которые используются для проведения инвентаризации и кадастрового учета земельных участков, объектов, размещенных на них [1].

Разработанные методические рекомендации соответствуют положениям гражданского законодательства, федеральным законам «О кадастре» и «О землеустройстве». В соответствии с рекомендациями даются разъяснения по проведению инвентаризации земельно-имущественного комплекса, по выявлению неучтенных объектов и проведению работ по землеустройству в границах муниципального образования. В соответствии с этим мы можем сделать вывод о том, что инвентаризация земельно-имущественного комплекса направлена на сбор и актуализацию данных по объектам, ранее поставленным на учет, на выявление 
правонарушений в сфере землепользования, на выявление объектов, которые не числятся на учете и подлежат включению в систему кадастрового учета.

Проведением инвентаризации земельно-имущественного комплекса в настоящее время занимаются органы местного самоуправления, землеустроительные организации, входящие в СРО, которые выигрывают муниципальные конкурс на проведение работ. Инвентаризация направлена на учет участков, сбор данных для включения участков в систему учета, для создания и актуализации сведений в единой базе по объектам земельно-имущественного комплекса на территории Новосибирской области. Объектами инвентаризации являются все земельные участки и объекты, расположенные в пределах границ конкретного муниципального образования [2].

Проведение инвентаризации земельно-имущественного комплекса организуется с учреждением рабочих комиссий на основе решения глав муниципальных образований. Рабочая комиссия имеет четкую организационную структуру. Рабочая комиссия организует и проводит инвентаризацию объектов земельноимущественного комплекса, оказывает содействие землеустроительным организациям при проведении ими инвентаризации, рассматривает материалы по результатам инвентаризации и готовит перечень рекомендаций для муниципальной власти с целью повышения эффективности использования земельно-имущественного комплекса. Финансирование работ по инвентаризации и кадастровому учету осуществляется за счет средств, заложенных в бюджете муниципальных образований.

Участки, находящиеся в индивидуальном пользовании, а также расположенные на них объекты, подлежат кадастровому учету при условии финансирования кадастровых работ самими гражданами. Проблему представляет дефицит бюджета муниципальных образований. Так, по данным инвентаризации от 2016 г. в р. п. Чаны установлено, что 34\% земельных участков, которые являются собственностью муниципального образования, в системе кадастрового учета числятся с неуточненными границами, а следовательно - площадью. Для проведения кадастровых работ в отношении таких участков требуется финансирование в объеме 12,4 млн. руб. При этом в структуре бюджета на инвентаризацию и кадастровый учет ежегодные затраты на превышают 450 тыс. руб. Следовательно, из-за наличия таких участков регулярно возникают споры в области землепользования, споры по размещению линейных объектов. Поэтому для совершенствования работы по инвентаризации земельно-имущественного комплекса и кадастрового учета требуется дополнительное финансирование. В частности, можно было бы обратить внимание на механизмы софинансирования работ с участием граждан и собственников предприятий [3].

До проведения инвентаризации в соответствии с утвержденными методическими рекомендациями организуется документальная проверка. Проведение инвентаризации организуется с использованием для этого рабочих планов. Органами местного самоуправления на этапе подготовки собираются сведения по объектам на основе данных из кадастрового реестра. Далее для проверки 
готовятся картографические материалы и планы, готовятся списки землепользователей. Для информационного обеспечения рабочей комиссии предусматривается использование спутниковых снимков и 3D-карт населенных пунктов в пределах муниципального образования. В соответствии с приведенными выше материалами определяются внешние границы земель муниципального образования, уточняются границы кадастровых кварталов, утверждается перечень объектов, подлежащих проверке в ходе выездных мероприятий. При этом инвентаризация земельно-имущественного комплекса производится в соответствии с заранее утвержденным планом. Для актуализации картографических данных используются данные спутниковой съемки, которые обрабатываются в ГИС-программе.

Для съемки в труднодоступной местности используются БПЛА (квадрокоптеры), которые делают серию снимков с воздуха. В ходе проведения инвентаризации выявляются нарушения в сфере землеустройства и землепользования. Члены рабочей комиссии по каждому такому нарушению составляют материалы для последующего привлечения нарушителей к ответственности. По результатам выездных мероприятий собирается большой объем данных, подлежащих оцифровке и внесению изменений в систему учета. Все выявленные, но ранее не учтенные земельные участки, после сбора данных в ходе инвентаризации подлежат постановке на учет. По результатам проведения проверки готовится детализированный отчет с использованием для этого методических рекомендаций. Непосредственным проведением полевых работ занимаются подрядные организации для сбора и актуализации геодезических данных в системе учета.

\section{БИБЛИОГРАФИЧЕСКИЙ СПИСОК}

1. Дубровский А.В., Ершов А.В., Новоселов Ю.А., Москвин В.Н. Элементы геоинформационного обеспечения инвентаризационных работ // Вестник СГУГИТ (Сибирского государственного университета геосистем и технологий). 2017. Т. 22. № 4. С. 78-91.

2. Папаскири Т.В. Информационное обеспечение землеустройства: монография. М.: Изд-во ГУЗ, 2013. 160 с.

3. Ермолаев О.П. Геоинформационное картографирование эрозии почв в регионе среднего Поволжья // Почвоведение. 2017. № 1. С. 130-144.

(С Д. С. Шулбаева, 2021 